\title{
MEKANISME GOOD CORPORATE GOVERNANCE TERHADAP NILAI PERUSAHAAN DENGAN LEVERAGE SEBAGAI VARIABEL INTERVENING PADA PERUSAHAAN MANUFAKTUR YANG TERDAFTAR DI BURSA EFEK INDONESIA TAHUN 2012-2018
}

\author{
Nardi Sunardi ${ }^{1)}$ \\ 1) dosen universitas pamulang, email : dosen01030@unpam.ac.id
}

\section{ARTICLES}

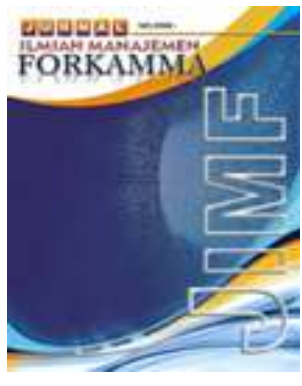

\section{JURNAL ILMIAH MANAJEMEN FORKAMMA}

Vol.2, No.3, Juli 2019 Halaman : $48-61$

(C) LPPM \& FORKAMMA

Prodi Magister Manajemen UNVERSITAS PAMULANG

ISSN (online) : :2599-171X ISSN (print) : :2598-9545

Keyword :

Good Corporate Governance, Leverage, Nilai Perusahaan

JEL. classification : C33, G20, G23, N65

Contact Author :

PRODI MAGISTER MANAJEMEN \& FORKAMMA UNPAM

JL.Surya Kencana No.1 Pamulang Tangerang Selatan - Banten

Telp. (021) 7412566, Fax (021) 7412491 Email :

jurnalforkamma.unpam@gmail.com
Tujuan "penelitian ini untuk menguji pengaruh secara parsial maupun simultan antara mekanisme good corporate governance terhadap nilai perusahaan dengan leverage sebagai variabel intervening pada perusahaan manufaktur",

"Populasi dalam penelitian ini adalah Industri Manufaktur di Indonesia 2012 sampai periode 2018 Sampel dalam penelitian ini adalah 14 Perusahaan Manufaktur di Indonesia sesuai dengan kriteria yang ditetapkan Analisis regresi dilakukan dengan didasarkan pada hasil analisis data panel atau pool data".

"Penelitian ini menyimpulkan beberapa hal sebagai berikut:. (1) Variabel Kepemilikan Institusional (KEI) berpengaruh negatif tidak signifikan terhadap Leverage (DER), (2). Kepemilikan Manajerial (KEM) berpengaruh positif tidak signifikan secara parsial terhadap Leverage (DER), (3). Komisaris Independen (KOI) berpengaruh negatif signifikan terhadap Leverage (DER), (4) Komite Audit (KOA) berpengaruh positif signifikan terhadap Leverage (DER), (5). KEI, KEM, KOI, dan KOA secara simultan terhadap Leverage (DER), dan mampu menjelaskan variabel Leverage sebesar 0.883391 atau 88,34 persen (6) Kepemilikan Institusional (KEI)) berpengaruh positif tidak signifikan terhadap Nilai Perusahaan (PBV) (7). Kepemilikan Manajerial (KEM) berpengaruh positif tidak signifikan Nilai Perusahaan (PBV) (8). Komisaris Independen (KOI) berpengaruh positif tidak signifikan terhadap Nilai Perusahaan (PBV) (9). Komite Audit (KOA) berpengaruh positif signifikan terhadap Nilai Perusahaan (PBV) (10) Leverage (DER) berpengaruh negatif tidak signifikan terhadap Nilai Perusahaan (PBV) (11) KEM, KEI, KOI, KOA dan CR secara simultan terhadap Nilai Perusahaan (PBV) Perusahaan Manufaktur di Indonesia periode 2012-2018, dan mampu menjelaskan variabel Nilai Perusahaan sebesar 0.674311 atau 67,43 persen". 


\section{A. Pendahuluan}

Perusahaan manufaktur "merupakan perusahaan yang memproduksi bahan baku menjadi bahan jadi, yang selanjutnya barang-barang yang telah jadi diproduksi lalu dijual. Berbeda dengan perusahaan dagang, dalam perusahaan manufaktur terjadi suatu proses produksi untuk mengolah bahan baku menjadi barang jadi dan selanjutnya Bagaimana memasarkan barang sudah jadi suoaya bisa terjual di pasaran. Siklus boom dan bust dalam ekonomi sering dikaitkan dengan jumlah perusahaan yang masuk dan keluar dari suatu industri. Selain terhadap perekonomian, dinamika perusahaan juga mempengaruhi penurunan output dan kesempatan kerja sektor manufaktur" (Nardi Sunardi A. A., 2018)

Pada dasarnya isu tentang corporate governance "dilatarbelakangi oleh agency theory yang menyatakan permasalahan agency muncul ketika pengelolaan suatu perusahaan terpisah dari kepemilikannya. Pemilik sebagai pemasok modal perusahaan mendelegasikan wewenangnya atas pengelolaan perusahaan kepada professional managers. Akibatnya, kewenangan untuk menggunakan sumber daya yang dimliki perusahaan sepenuhnya ada di tangan eksekutif. Hal itu menimbulkan kemungkinan terjadinya moral hazard dimana manajemen tidak bertindak yang terbaik untuk kepentingan pemilik karena adanya perbedaan kepentingan (conflict of interest). Manajer dengan informasi yang dimilikinya bisa bertindak hanya untuk menguntungkan dirinya sendiri dengan mengorbankan kepentingan pemilik karena manajer memiliki informasi perusahaan yang tidak dimiliki pemilik (asymmetry information). Hal ini akan mempengaruhi kinerja perusahaan dan menghilangkan kepercayaan investor terhadap pengembalian (return) atas investasi yang telah mereka tanam pada perusahaan tersebut". (Veno, 2015)

Good Corporate Governance sebagai "variabel pemoderasi Selain memiliki kinerja keuangan yang baik perusahaan juga diharapkan memiliki tata kelola yang baik. Dalam penelitian ini indikator mekanisme GCG yang digunakan adalah proporsi komisaris independen. Adanya komisaris independen diharapkan mampu meningkatkan peran dewan komisaris sehingga tercipta Good Corporate Governance di dalam perusahaan. Manfaat Corporate Governance akan dilihat dari premium yang bersedia dibayar oleh investor atas ekuitas perusahaan (harga pasar). Jika ternyata investor bersedia membayar lebih mahal, maka nilai pasar perusahaan yang menerapkan GCG juga akan lebih tinggi dibanding perusahaan yang tidak menerapkan atau mengungkapkan praktek GCG mereka. Mekanisme corporate governance (CG) sebagai upaya penegakan praktik CG dalam perusahaan diharapkan dapat mengurangi konflik keagenan dan juga diharapkan mampu untuk mengontrol biaya keagenan (Iturriaga dan Sanz 1998) dalam " (Andriyan \& Supatmi, Desember 2010)

\section{B. Tinjauan Pustaka.}

\section{Teori Keagenan (Agency Theory)}

Teori ini diperkenalkan pertama kali oleh Jensen \& Meckling, 1976 biasa disebut dengan teori keagenan (agency theory) menurut teori keagenan Jensen at al. mendefinisikan "biaya keagenan sebagai jumlah biaya yang dikeluarkan berkaitan dengan structuring, administering dan enforcing contracts (baik formal maupun informal) dtambah residual loss. Enforcemen costs termasuk didalamnya biaya monitoring dan binding (pembentukan / pengikatan hubungan yang ada) yaitu sumber daya yang dihabiskan oleh principal (pemegang saham/pemilik perusahaan) dan agent (manajer) untuk menjamin berjalannya contract enforcement. Residual costs meliputi opportunity loss (kesempatan yang hilang) pada saat kontrak yang telah optimal tetapi tidak dilaksanaan secara sempurna. Sehingga dapat dikatakan bawa biaya keagenan mencakup seluruh biaya 
yang mengacu pada contracting cost, transaction cost, moral hazard costs, dan information costs. yaitu pendesainan kontrak yang tepat untuk menyelaraskan kepentingan prinsipal dan agen dalam hal terjadi konflik kepentingan". (Jensen \& Meckling, 1976). (Eisenhardt, 1989) dalam (Sunardi L. H., 2017) "menyatakan bahwa teori keagenan menggunakan tiga asumsi yaitu: (1) asumsi tentang sifat manusia (human assumptions), (2) asumsi tentang keorganisasian (organizational assumptions), dan (3) asumsi tentang informasi (Information assumptions). Asumsi sifat manusia dikelompokkan menjadi tiga yaitu: (1) self-interest, yaitu sifat manusia yang mengutamakan kepentingan diri sendiri, (2) bounded-rationality, yaitu sifat manusia yang memiliki keterbatasan rasionalitas, (3) risk aversion yaitu sifat manusia yang cenderung memilih menghindari resiko. Asumsi keorganisasian dikelompokkan menjadi tiga, yaitu : (1) konflik sebagai tujuan antar partisipan, (2) efisiensi sebagai suatu kriteria efektivitas, dan (3) asimetri informasi antara principal dan agen".

"Posisi agent sebagai pemegang kunci informasi dan principal sebagai penerima informasi dari agent dapat memicu munculnya suatu kondisi yang disebut sebagai asimetri informasi (information asymetri), yaitu suatu kondisi dimana informasi yang diperoleh oleh pihak manajemen sebagai penyedia informasi (preparer) dengan pihak principal secara umum tidak seimbang. Menurut (Jensen \& Meckling, 1976) terdapat dua macam asimetri informasi yaitu: 1. Adverse Selection, 2. Moral Hazard Asimetri antara manajemen dengan pemilik memberikan kesempatan kepada manajer untuk berlaku opportunis untuk memperoleh keuntungan pribadi. Misalnya dengan tidak menyampaikan laporan keuangan sesuai dengan kenyataan yang sebenarnya untuk mendapatkan bonus pribadi. Manajer dapat malakukan manajemen laba untuk menyesatkan pemilik mengenai kinerja ekonomi perusahaan" (Nardi Sunardi, 2018).

\section{Nilai Perusahaan}

Nilai perusahaan "merupakan kondisi tertentu yang telah dicapai oleh suatu perusahaan dan nilai perusahaan sebagai gambaran dari kepercayaan masyarakat terhadap perusahaan" (Sunardi, 2017). Tujuan utama perusahaan menurut theory of the firm (Jensen \& Meckling, 1976), "adalah untuk memaksimumkan kekayaan atau nilai perusahaan (value of the firm). Memaksimalkan nilai perusahaan sangat penting artinya bagi suatu perusahaan, karena dengan memaksimalkan nilai perusahaan berarti juga memaksimalkan kemakmuran pemegang saham yang merupakan tujuan utama perusahaan".

Keown AJ, Martin JD, Fetty JW, Scott, JR DF (2010:277) mengemukakan "nilai perusahaan merupakan nilai pasar atas surat berharga utang dan ekuitas perusahaan yang beredar. Nilai perusahaan merupakan persepsi investor terhadap tingkat keberhasilan perusahaan yang sering dikaitkan dengan harga saham" (Keown AJ, 2010).

Nilai perusahaan sangat penting karena mencerminkan seberapa besar perusahaan tersebut dapat memberikan keuntungan bagi perusahaan khususnya pemilik dan investor. (Sunardi \& Permana, 2019 ) Untuk dapat memaksimalkan nilai perusahaan tersebut maka peusahaan atau pengelola dihadapkan pada keputusan keuangan yang meliputi keputusan investasi, keputusan pendanaan dan keputusan pengolahan keuangan serta pembagian keuntungan atas deviden dari hasil keuntungan atau profit perusahaan" (Sunardi N. , 2018) 


\section{Good Corporate Governance}

Gray and Radebaugh dalam (Bukhori \& Raharja, 2012) "menggambarkan sebuah mekanisme corporate governance yang dibagi ke dalam dua struktur. Mekanisme merupakan suatu aturan main, prosedur dan hubungan yang jelas antara pihak yang mengambil keputusan dengan pihak yang melakukan kontrol terhadap keputuan tersebut. Pertama adalah struktur mekanisme pengendalian internal perusahaan. Pihak- pihak yang terlibat dalam mekanisme internal ini adalah agent dan principal yang terdiri komposisi board of directors dan executive manajer di dalam perusahaan. Yang kedua adalah struktur mekanisme pengendalian eksternal. Struktur mekanisme pengendalian external terdiri dari stakeholder yang berkepentingan dan berhubungan dengan perusahaan antara lain Pasar Modal, Pasar Uang, Auditor, Paralegal dan regulator.Struktur mekanisme pengendalian eksternal merupakan mekanisme pengendalian yang dibentuk pihak dari luar perusahaan".

Brigham dan Erhardt dalam (Dewayanto, 2010) "tata kelola perusahaan didefinisikan sebagai seperangkat aturan dan prosedur yang menjamin manajer untuk menerapkan prinsip-prinsip manajemen berbasis nilai. Prinsip-prinsip tersebut dalam penerapannya dikenal dengan dengan istilah TARIF yaitu Transparency, Accountability, Responsibility, Independency dan Fairness . Esensi tata kelola perusahaan adalah untuk memastikan bahwa tujuan pemegang saham utama-kekayaan manajemen diimplementasikan. The Bassel Committee on Banking Supervision-Federal Reserve menetapkan bahwa bank merupakan suatu komponen kritis ekonomi. Mereka menyediakan pembiayaan perusahaan komersial, layanan keuangan dasar untuk segmen yang luas dan akses sistem pembayaran. Pentingnya bank ekonomi nasional digarisbawahi oleh kenyataan bahwa perbankan secara universal sebuah industri regulator yang memiliki akses ke jaring pengaman pemerintah. Ini sangat penting, oleh karena itu bank memiliki tata kelola perusahaan yang kuat". Menurut (FCGI, 2001) "pengertian good corporate governance adalah : Seperangkat peraturan yang menetapkan hubungan antara pemegang saham, pengurus, pihak kreditur, pemerintah, karyawan serta para pemegang kepentingan internal dan eksternal lainnya sehubungan dengan hak-hak dan kewajiban mereka, atau dengan kata lain sistem yang mengarahkan dan mengendalikan perusahaan. Dari penjelasan di atas maka dapat disimpulkan bahwa Good Corporate Governance adalah rangkaian proses terstruktur yang digunakan manajemen perusahaan untuk mengelola perusahaan dengan tujuan untuk meningkatkan nilainilai perusahaan serta kontinuitas usaha perusahaan. Dengan adanya good corporate governance, diharapkan nilai perusahaan akan dinilai baik oleh investor".

"Prinsip Good Corporate Governance salah satu pilar penting dalam good corporate governance di perbankan adalah komitmen penuh dari seluruh jajaran pengurus bank hingga pegawai yang terendah untuk melaksanakan ketentuan tersebut. Maka dari itu seluruh karyawan wajib untuk menjunjung tinggi prinsip good corporate governance. Dalam penerapannya, (OECD, 1999) menyusun prinsip-prinsip yang mengatur good corporate governance, diantaranya: seperti Transparency, Accountability, Responsibility, Independency dan Fairness (TARIF) seperti halnya sebagai berikut: 1 . Transparency (Transparansi) Keterbukaan dalam mengemukakan informasi yang material dan relevan serta keterbukaan dalam melaksanakan proses pengambilan keputusan 2 . Accountablity (Akuntabilitas) Merupakan kejelasan fungsi, struktur, sistem, dan 

secara efektif. 3. Responsibility (Pertanggungjawaban) Adanya kesesuaian (kepatuhan) di dalam pengelolaan bank terhadap prinsip korporasi yang sehat seta peraturan perundangan yang berlaku. 4. Independency (Independensi) Pengelolaan bank secara profesional tanpa pengaruh/tekanan dari pihak manapun. 5. Fairness (Kesetaraan dan Kewajaran) Keadilan dan kesetaraan dalam memenuhi hak-hak stakeholders yang timbul berdasarkan perjanjian serta peraturan perundangan yang berlaku. Prinsip ini menekankan bahwa semua pihak baik pemegang saham minoritas maupun asing harus diperlakukan sama atau setara". (Sari, 2010)

\section{Perumusan Masalah}

Berpangkal dari latar belakang masalah seperti yang telah diuraikan diatas, Perumusan masalah sebagai berikut

1. Bagaimana pengaruh Kepemilikan Institusional (KEl), secara parsial terhadap Leverage (DER)?

2. Bagaimana pengaruh Kepemilikan Manajerial (KEM) secara parsial terhadap Leverage (DER)?

3. Bagaimana pengaruh Komisaris Independen (KOl) secara parsial terhadap Leverage (DER)?

4. Bagaimana pengaruh Komite Audit (KOA) secara parsial terhadap Leverage (DER)?

5. Bagaimana pengaruh $\mathrm{KEI}, \mathrm{KEM}, \mathrm{KOI}$, dan $\mathrm{KOA}$ secara simultan terhadap Leverage (DER)?

6. Bagaimana pengaruh Kepemilikan Institusional (KEl), secara parsial terhadap Nilai Perusahaan (PBV)?

7. Bagaimana pengaruh Kepemilikan Manajerial (KEM) secara parsial terhadap Nilai Perusahaan (PBV)?

8. Bagaimana pengaruh Komisaris Independen (KOl) secara parsial terhadap Nilai Perusahaan (PBV)?

9. Bagaimana pengaruh Komite Audit (KOA) secara parsial terhadap Nilai Perusahaan (PBV)?

10. Bagaimana pengaruh Likuiditas (CR) secara parsial terhadap Nilai Perusahaan (PBV)?

11. Bagaimana pengaruh $\mathrm{KEI}, \mathrm{KEM}, \mathrm{KOI}, \mathrm{KOA}$ dan $\mathrm{CR}$ secara simultan terhadap Nilai Perusahaan (PBV)?

\section{Tujuan Penelitian}

1. Untuk menganalisis dan mengetahui pengaruh Kepemilikan Institusional (KEl), secara parsial terhadap Leverage (DER)

2. Untuk menganalisis dan mengetahui pengaruh Kepemilikan Manajerial (KEM) secara parsial terhadap Leverage (DER)

3. Untuk menganalisis dan mengetahui pengaruh Komisaris Independen (KOl) secara parsial terhadap Leverage (DER)

4. Untuk menganalisis dan mengetahui pengaruh Komite Audit (KOA) secara parsial terhadap Leverage (DER)

5. Untuk menganalisis dan mengetahui pengaruh $\mathrm{KEI}, \mathrm{KEM}, \mathrm{KOl}$, dan $\mathrm{KOA}$ secara simultan terhadap Leverage (DER) 
6. "Untuk menganalisis dan mengetahui pengaruh Kepemilikan Institusional (KEI), secara parsial terhadap Nilai Perusahaan (PBV)

7. Untuk menganalisis dan mengetahui pengaruh Kepemilikan Manajerial (KEM) secara parsial terhadap Nilai Perusahaan (PBV)

8. Untuk menganalisis dan mengetahui pengaruh Komisaris Independen (KOI) secara parsial terhadap Nilai Perusahaan (PBV)

9. Untuk menganalisis dan mengetahui pengaruh Komite Audit (KOA) secara parsial terhadap Nilai Perusahaan (PBV)

10. Untuk menganalisis dan mengetahui pengaruh Likuiditas $(C R)$ secara parsial terhadap Nilai Perusahaan (PBV)

11. Untuk menganalisis dan mengetahui pengaruh $\mathrm{KEI}, \mathrm{KEM}, \mathrm{KOI}, \mathrm{KOA}$ dan $\mathrm{CR}$ secara simultan terhadap Nilai Perusahaan (PBV)"

\section{Research Model}

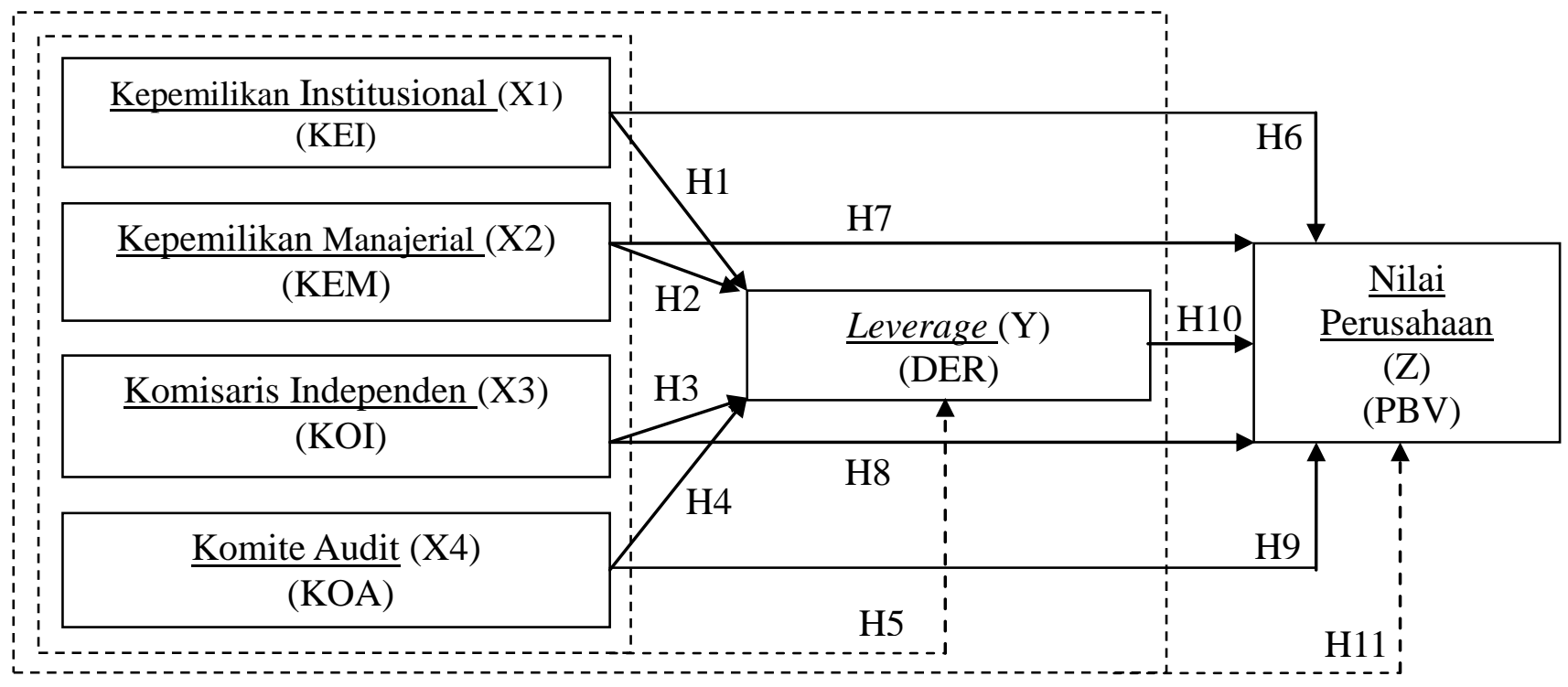

\section{E. Metodologi}

Jenis Penelitian ini menggunakan pendekatan kuantitatif yang merupakan masingmasing variabel maupun antar variabel didasari pada skala pengukuran kuantitatif Dalam penelitian ini teknik pengambilan sample dilakukan secara purposive sampling dengan kriteria sebagai berikut :

1. Perusahaan Manufaktur yang terdaftar di BEI selama tahun 2012-2018;

2. Perusahaan yang menerbitkan annual report dan laporan keuangan secara lengkap dan konsisten selama tahun 2012 - 2018;

3. Menyajikan laporan keuangan dalam satuan rupiah selama tahun 2012-2018;

4. Laporan keuangan dengan laba tidak minus (rugi 2 tahun atau lebih)

5. Perusahaan manufaktur yang menyediakan informasi lengkap tentang kepemilikan manajerial, kepemilikan institusional, komisaris independen dan 


\section{Sampel Penelitian:}

\begin{tabular}{ccl}
\hline No & Kode & Perusahaan Manufaktur di Indonesia \\
\hline 1 & AUTO & PT Astra Otoparts Tbk \\
2 & BTON & PT Betonjaya Manunggal Tbk \\
3 & GJTL & PT Gajah Tunggal Tbk \\
4 & INAI & PT Indal Aluminium Industry Tbk \\
5 & KAEF & PT Kimia Farma (Persero) Tbk \\
6 & KDSI & PT Kedawung Setia Industrial Tbk \\
7 & KICI & PT Kedaung Indah Can Tbk \\
8 & LION & PT Lion Metal Works Tbk \\
9 & LMPI & PT Langgeng Makmur Industri Tbk \\
10 & PICO & PT Pelangi Indah Canindo Tbk \\
11 & SKLT & PT Sekar Laut Tbk \\
12 & SMSM & PT Selamat Sempurna Tbk \\
13 & ULTJ & PT Ultra Jaya Milk Industry Tbk \\
14 & VOKS & PT Voksel Electric Tbk \\
\hline
\end{tabular}

Variabel Oprasional:

\begin{tabular}{|c|c|c|c|}
\hline Variabel & Proxy & Ukuran Rasio & Scale \\
\hline $\begin{array}{l}\text { Nilai Perusahaan } \\
\text { (Z) }\end{array}$ & PBV & PBV $\frac{\text { Harga saham }}{\text { BV Saham }}$ & Ratio \\
\hline Leverage $(\mathrm{Y})$ & DER & DER $=\frac{\text { Total Utang }}{\text { Total Aset }}$ & Ratio \\
\hline $\begin{array}{l}\text { Kepemilikan } \\
\text { Intitusional (X1) }\end{array}$ & KEI & $\mathrm{KEI}=\frac{\text { Kepemilikan Intitusional }}{\text { Total Kepemilikan }}$ & Ratio \\
\hline $\begin{array}{l}\text { Kepemilikan } \\
\text { Manajerial (X2) }\end{array}$ & KEM & KEM $=\frac{\text { Kepemilikan Manajerial }}{\text { Total Kepemilikan }}$ & Ratio \\
\hline $\begin{array}{l}\text { Komisaris } \\
\text { Independen (X3) }\end{array}$ & $\mathrm{KOI}$ & $\mathrm{KOI}=\frac{\text { Komisaris Indenpenden }}{\text { Jumlah komisaris }}$ & Ratio \\
\hline Komite Audit (X4) & $\mathrm{KOA}$ & Jumlah Komite Audit & Ratio \\
\hline
\end{tabular}

"Metode analisis data yang dilakukan dalam penelitian ini menggunakan metode analisis regresi data panel. Untuk menentukan salah satu dari tiga pendekatan regresi panel yang akan digunakan yaitu ordinary least square (OLS) atau common effect model, fixed effect model, random effect model. maka dilakukan Chow test dan Hausman test. Untuk mengolah data sekunder yang didapat, peneliti mengunakan program aplikasi bantuan software statistik diantaranya MS.Exel 2010 meliputi pembuatan tabel dan grafik untuk analisis deskriptif. Sedangkan kegiatan pengolahan data dengan EVIEWS versi 10.0 digunakan untuk membantu dalam menganalisis data yang digunakan dalam melakukan pengujian signifikasi analisis regresi data panel." (Sugiyono., 2012) 


\section{F. Hasil dan Pembahasan}

\section{Hasil}

1. Deskripsi Statatistik.

"Deskripsi Statatistik mekanisme good corporate governance terhadap nilai perusahaan dengan leverage sebagai variabel intervening pada perusahaan manufaktur yang tercatat di IDX (Indonesia Stock Exchange) selama priode 2012-2018 adalah sbb" :

\begin{tabular}{lcccccc}
\hline & PBV & DER & KEI & KEM & KOI & KOA \\
\hline Mean & 1.534806 & 1.166939 & 68.80491 & 5.826561 & 36.39883 & 41.14064 \\
Median & 0.862000 & 0.925000 & 71.53600 & 0.290000 & 33.33000 & 42.85700 \\
Maximum & 6.724000 & 6.340000 & 99.82300 & 33.84400 & 50.00000 & 100.0000 \\
Minimum & 0.120000 & 0.170000 & 29.07200 & 0.001000 & 20.00000 & 14.29000 \\
Std. Dev. & 1.585451 & 1.046711 & 17.14496 & 8.629149 & 9.699690 & 15.86446 \\
Skewness & 1.542719 & 2.089939 & -0.277049 & 1.835164 & 0.167355 & 0.542370 \\
Kurtosis & 4.378519 & 9.106636 & 2.201016 & 5.956163 & 2.010712 & 3.862143 \\
& & & & & & \\
Jarque-Bera & 46.63267 & 223.6130 & 3.860386 & 90.69172 & 4.453776 & 7.839801 \\
Probability & 0.000000 & 0.000000 & 0.145120 & 0.000000 & 0.107864 & 0.019843 \\
Sum & 150.4110 & 114.3600 & 6742.881 & 571.0030 & 3567.085 & 4031.783 \\
Sum Sq. Dev. & 243.8245 & 106.2735 & 28513.10 & 7222.835 & 9126.146 & 24413.08 \\
& & & & & & \\
\hline $\begin{array}{l}\text { Observations } \\
\text { Cross }\end{array}$ & 98 & 98 & 98 & 98 & 98 & 98 \\
sections & 14 & 14 & 14 & & & \\
\hline
\end{tabular}

\section{Determinan Leverage.}

Berdasarkan pengujian berpasangan terhadap ketiga model regresi data panel, Kesimpulan sbb :"

\begin{tabular}{|c|l|c|c|}
\hline No & \multicolumn{1}{|c|}{ Metode } & Pengujian & Hasil \\
\hline 1. & Uji Chow-Test & common effect $v$ s fixed effect & fixed effect \\
\hline 2. & Langrage Multiplier (LM-test) & common effect vs random effect & random effect \\
\hline 3. & Haustman Test & fixed effect $v$ s random effect & fixed effect \\
\hline
\end{tabular}

Estimasi Model Regresi Data Panel secara Parsial (Uji T) dan Simultan (Uji F) Model Fixed Effects dengan White-Test.) sbb:

\begin{tabular}{crrrr}
\hline \hline Variable & Coefficient & Std. Error & t-Statistic & Prob. \\
\hline \hline C & 1.230070 & 0.363605 & 3.382983 & 0.0011 \\
KEI? & -0.000753 & 0.005260 & -0.143224 & 0.8865 \\
KEM? & 0.011351 & 0.006378 & 1.779647 & 0.0789 \\
KOI? & -0.006436 & 0.001948 & -3.303988 & 0.0014 \\
KOA? & 0.003812 & 0.001354 & 2.816194 & 0.0061 \\
Fixed Effects (Cross) & & & & \\
AUTO--C & -0.727832 & & & \\
-BTON--C & -1.014720 & & & \\
_GJTL--C & 0.891892 & & &
\end{tabular}




$\begin{array}{cr}\text { INAI--C } & 2.726678 \\ \text {-KAEF--C } & -0.242108 \\ \text {-KDSI--C } & 0.290120 \\ \text { - KICI--C } & -0.570125 \\ \text { - LION--C } & -0.715184 \\ \text {-LLMPI--C } & 0.102996 \\ \text { _LPICO--C } & 0.575195 \\ \text {-PSKLT--C } & 0.126623 \\ \text {-SMSM--C } & -0.694457 \\ \text {-SMSMJ-C } & -1.086254 \\ \text {-ULTJ--C } & 0.337175\end{array}$

Effects Specification

Cross-section fixed (dummy variables)

Weighted Statistics

\begin{tabular}{lllr}
\hline \hline R-squared & 0.903828 & Mean dependent var & 1.977941 \\
Adjusted R-squared & 0.883391 & S.D. dependent var & 1.138174 \\
S.E. of regression & 0.452491 & Sum squared resid & 16.37983 \\
F-statistic & 44.22581 & Durbin-Watson stat & 1.022932 \\
Prob(F-statistic) & 0.000000 & & \\
\hline
\end{tabular}

Unweighted Statistics

\begin{tabular}{llll}
\hline \hline R-squared & 0.826865 & Mean dependent var & 1.166939 \\
Sum squared resid & 18.39963 & Durbin-Watson stat & 1.280666 \\
\hline \hline
\end{tabular}

Hasil Estimasi Regresi Data Panel untuk fixed effect sbb :

\begin{tabular}{|c|c|c|c|c|}
\hline \multirow{2}{*}{ Model } & Adjusted $\boldsymbol{R}^{\mathbf{2}}$ & $\begin{array}{c}\text { Prob. } \\
\text { (F-stat.) } \boldsymbol{\alpha}-\mathbf{0 , 0 5}\end{array}$ & \multicolumn{2}{|c|}{ Probabilitas $\boldsymbol{\alpha}-\mathbf{0 , 0 5}$} \\
\hline \multirow{3}{*}{ fixed effect } & 0.883391 & \multirow{2}{*}{0.0000} & KEl & Tidak Signifikan \\
\cline { 3 - 5 } & & & KEM & Tidak Signifikan \\
\cline { 3 - 5 } & & & KOI & Signifikan \\
\cline { 3 - 5 } & & & KOA & Signifikan \\
\hline
\end{tabular}

\section{Implikasi Nilai Perusahaan}

"Berdasarkan pengujian berpasangan terhadap ketiga model regresi data panel, Kesimpulan sbb :

\begin{tabular}{|c|l|c|c|}
\hline No & \multicolumn{1}{|c|}{ Metode } & Pengujian & Hasil \\
\hline 1. & Uji Chow-Test & common effect vs fixed effect & fixed effect \\
\hline 2. & Langrage Multiplier (LM-test) & common effect vs random effect & Random effect \\
\hline 3. & Haustman Test & fixed effect vs random effect & fixed effect \\
\hline
\end{tabular}


"Estimasi Model Regresi Data Panel secara Parsial (Uji T) dan Simultan (Uji F) Model fixed effect dengan White-Test.)" sbb:

\begin{tabular}{crrrr}
\hline \hline Variable & Coefficient & Std. Error & t-Statistic & Prob. \\
\hline \hline C & 0.829682 & 0.556654 & 1.490480 & 0.1401 \\
DER? & -0.023343 & 0.063576 & -0.367161 & 0.7145 \\
KEI? & 0.002306 & 0.007740 & 0.297919 & 0.7665 \\
KEM? & 0.001025 & 0.021122 & 0.048508 & 0.9614 \\
KOI? & 0.002308 & 0.004537 & 0.508675 & 0.6124 \\
KOA? & 0.011758 & 0.004664 & 2.521005 & 0.0137 \\
Fixed Effects (Cross) & & & \\
_AUTO--C & -0.213665 & & & \\
-BTON--C & -1.230863 & & & \\
-GJTL--C & -0.525021 & & & \\
_INAI--C & -0.859152 & & & \\
-KAEF--C & 2.411047 & & & \\
-KDSI--C & -1.137905 & & & \\
-KICI--C & -1.054743 & & & \\
-LION--C & -0.558101 & & & \\
-LMPI--C & -0.971105 & & & \\
-PICO--C & -1.263995 & & & \\
_SKLT--C & 0.388260 & & & \\
_SMSM--C & 2.724627 & & & \\
-ULTJ--C & 1.933096 & & & \\
-VOKS--C & 0.357520 & & & \\
\hline \hline
\end{tabular}

Effects Specification

Cross-section fixed (dummy variables)

Weighted Statistics

\begin{tabular}{llll}
\hline \hline R-squared & 0.734748 & Mean dependent var & 1.855437 \\
Adjusted R-squared & 0.674311 & S.D. dependent var & 0.913775 \\
S.E. of regression & 0.779733 & Sum squared resid & 48.03074 \\
F-statistic & 12.15721 & Durbin-Watson stat & 1.629272 \\
Prob(F-statistic) & 0.000000 & & \\
\hline \hline
\end{tabular}

Unweighted Statistics

\begin{tabular}{llll}
\hline \hline R-squared & 0.749032 & Mean dependent var & 1.534806 \\
Sum squared resid & 61.19218 & Durbin-Watson stat & 1.716333 \\
\hline
\end{tabular}

Hasil Estimasi Regresi Data Panel untuk Fixed Effect sbb :

\begin{tabular}{|c|c|c|c|c|}
\hline \multirow{2}{*}{ Model } & Adjusted $\boldsymbol{R}^{\mathbf{2}}$ & $\begin{array}{c}\text { Prob. } \\
\text { (F-stat.) } \boldsymbol{\alpha} \\
\mathbf{- 0 , 0 5}\end{array}$ & \multicolumn{2}{|c|}{ Probabilitas $\mathbf{\alpha}-\mathbf{0 , 0 5}$} \\
\hline \multirow{3}{*}{ Fixed Effect } & \multirow{3}{*}{0.674311} & \multirow{2}{*}{0.0000} & CR & Tidak Signifikan \\
\cline { 4 - 5 } & & & KEI & Tidak Signifikan \\
\cline { 3 - 5 } & & KOI & Tidak Signifikan \\
\cline { 3 - 5 } & & KOA & Tidak Signifikan \\
\cline { 3 - 5 } & & & &
\end{tabular}


4. Mekanisme good corporate governance terhadap nilai perusahaan dengan leverage sebagai variabel intervening : Analisis Gabungan

"Tabel dibawah ini menjelaskan gabungan dua model regresi data panel, pada model pertama, menjelaskan tentang determinan laverage, dengan hasil KEI, KEM, KOI, KOA secara simultan berpengaruh signifikan terhadap leverage (DER). selanjutnya model kedua menjelaskan tentang implikasi pada nilai perusahaan dengan hasil bahwa KEI, $\mathrm{KEM}, \mathrm{KOI}, \mathrm{KOA}$ dan DER secara simultan berpengaruh signifikan terhadap nilai perusahaan (PBV) " sbb:

\begin{tabular}{|c|c|c|c|c|c|c|}
\hline \multirow{2}{*}{$\begin{array}{c}\text { Variabel } \\
\text { Bebas }\end{array}$} & \multicolumn{3}{|c|}{$\begin{array}{c}\text { Model 1 } \\
\text { Determinan Leverage }\end{array}$} & \multicolumn{3}{c|}{$\begin{array}{c}\text { Model 2 } \\
\text { Imlikasi Nilai Perusahaan }\end{array}$} \\
\cline { 2 - 7 } & $\begin{array}{c}\text { Koefisien } \\
\text { Regresi }\end{array}$ & Prob. & $\begin{array}{c}\text { Sign./Tdk. } \\
\text { Sign. }\end{array}$ & $\begin{array}{c}\text { Koefisien } \\
\text { Regresi }\end{array}$ & Prob. & $\begin{array}{c}\text { Sign./Tdk. } \\
\text { Sign. }\end{array}$ \\
\hline DER & - & - & - & -0.023343 & 0.7145 & Tdk.Sign. \\
\hline KEI & -0.000753 & 0.8865 & Tdk.Sign. & 0.002306 & 0.7665 & Tdk.Sign. \\
\hline KEM & 0.011351 & 0.0789 & Tdk.Sign. & 0.001025 & 0.9614 & Tdk.Sign. \\
\hline KOI & -0.006436 & 0.0014 & Signifikan & 0.002308 & 0.6124 & Tdk.Sign. \\
\hline KOA & 0.003812 & 0.0061 & Signifikan & 0.011758 & 0.0137 & Signifikan. \\
\hline
\end{tabular}

Sumber : Data yang diolah penulis, 2019

\section{G. Kesimpulan}

1. "Kepemilikan Intitusional (KEI) berpengaruh negatif tidak signifikan secara parsial terhadap Leverage (DER) dengan demikian variabel Kepemilikan Intitusional mempengaruhi Leverage perusahaan manufaktur yang tercatat di BEI selama priode $2012-2018$.

2. Kepemilikan Manajerial (KEM) berpengaruh positif tidak signifikan secara parsial terhadap Leverage (DER) dengan demikian variabel Kepemilikan Manajerial tidak mempengaruhi Leverage perusahaan manufaktur yang tercatat di BEI selama priode 2012-2018.

3. Komisaris Independen (KOI) berpengaruh negatif signifikan secara parsial terhadap Leverage (DER) dengan demikian variabel Komisaris Independen mempengaruhi Leverage perusahaan manufaktur yang tercatat di BEI selama priode 2012-2018.

4. Komite Audit (KOA) berpengaruh positif signifikan secara parsial terhadap Leverage (DER) dengan demikian variabel public ownership mempengaruhi Leverage perusahaan manufaktur yang tercatat di BEI selama priode 2012-2018.

5. KEI, KEM, KOI, KOA secara simultan berpengaruh positif dan signifikan terhadap Leverage (DER) pada perusahaan manufaktur yang tercatat di BEI selama priode 2012-2018, dan mampu menjelaskan variabel Leverage sebesar 0.883391 , atau 88,34 persen sedangkan sisanya $11.66 \%(100 \%-88,34 \%)$ dipengaruhi oleh variabel lain yang tidak ada didalam penelitian ini.

6. Kepemilikan Intitusional (KEI) berpengaruh positif tidak signifikan secara parsial terhadap Nilai Perusahaan (PBV) dengan demikian variabel Kepemilikan Intitusional tidak mempengaruhi nilai perusahaan manufaktur yang tercatat di BEI selama priode $2012-2018$.

7. Kepemilikan Manajerial (KEM) berpengaruh positif tidak signifikan secara parsial terhadap Nilai Perusahaan (PBV) dengan demikian variabel Kepemilikan Manajerial tidak mempengaruhi Nilai Perusahaan manufaktur yang tercatat di BEI selama priode $2012-2018$.

8. Komisaris Independen (KOI) berpengaruh positif tidak signifikan secara parsial terhadap Nilai Perusahaan (PBV) dengan demikian variabel Komisaris Independen tidak mempengaruhi Nilai Perusahaan manufaktur yang tercatat di BEI selama priode 2012-2018. 
9. Komite Audit (KOA) berpengaruh positif signifikan secara parsial terhadap Nilai Perusahaan (PBV) dengan demikian variabel Komite Audit mempengaruhi Nilai Perusahaan manufaktur yang tercatat di BEI selama priode 2012-2018.

10. $\mathrm{KEI}, \mathrm{KEM}, \mathrm{KOI}, \mathrm{KOA}$ secara simultan berpengaruh positif dan signifikan terhadap Nilai Perusahaan (PBV) pada perusahaan manufaktur yang tercatat di BEI selama priode 2012-2018, dan mampu menjelaskan variabel Nilai Perusahaan sebesar 0.674311 atau 67,43 persen sedangkan sisanya $32.57 \%(100 \%-67,43$ $\%)$ dipengaruhi oleh variabel lain yang tidak ada didalam penelitian ini".

\section{Saran :}

1. "Untuk menurunkan leverage atau kesehatan perusahaan, manajer atau direksi perusahaan yang tergabung dalam industri manufaktur harus meningkatkan Komisaris Independen lebih banyak pengawasan terhadap kesehatan perusahaan.

2. Kebijakan menurunkan leverage atau kesehatan perusahaan, manajer atau direksi perusahaan yang tergabung dalam industri manufaktur harus menurunkan Komite Audit supaya lebih terawasi sistem keuangan perusahaan.

3. Manajemen dalam meningkatkan nilai perusahaan harus menambah jumlan Komite Audit.

4. Secara simultan direksi dan pengelola dalam menurunkan leverage dan meningkatkan nilai perusahan manufaktur manajemen harus selalu memperhatikan struktur kepemilikan, Komisaris Independen, Komite Audit" 


\section{Daftar Pustaka}

"Altman, E. I. (1968). Financial Ratios, Discriminant Analysis and the Prediction of Corporate.

Andriyan, O., \& Supatmi. (Desember 2010). Pengaruh Mekanisme Corporate Governance terhadap Kinerja Keuangan Bank Perkeriditan Rakyat. Jurnal Akuntansi dan Keuangan Indonesia Volume 7 - No. 2, 187-204.

Bambang Juanda, J. (2012). Ekonometrika Deret \& Waktu, Teori \& Aplikasi. Bogor:: Penerbit IPB Press PT.

Brigham, E., \& Houston, J. (2013). "Dasar-Dasar Manajemen Keuangan" di terjemahkan oleh Ali Akbar Yulianto. Jakarta: PT. Salemba Empat.

Bukhori, I., \& Raharja. (2012). Pengaruh good corporate governance dan ukuran perusahaan terhadap Kinerja Perusahaan. Diponogoro Journal of Accounting, 112.

Dewayanto, T. (2010). The Effect Mechanism Good Corporate Governance on the Performance National Banking Study on banking company are listed in Indonesia Stock Exchange in the period 2006-2008. Fokus Ekonomi, 104 - 123.

Dewi Utari, P. A. (2014). Manajemen Keuangan; Kajian Praktik dan Teori dalam Mengelola Keuangan Organisasi Perusahaan. Jakata: Mitra Wacana Media.

Eisenhardt, K. (1989). Agency Theory: An Assessment and Review. Academy of Management Review, Vol. 14, No. 1, 57-74.

FCGI. (2001). Corporate Governance. Forum for Corporate Governance in Indonesia. Jakarta.

Guitman LJ, Z. C. (2012). Principles of Managerial Financial Global Edition 13th Edition. England:: Person Education Limited 2012.

Jensen, M., \& Meckling, W. (1976). Theory of The Firm: Managerial Behaviour,Agency Cost and Ownership Structure. Journal of Financial Economics 3, 305-360.

Kadim, A., \& Sunardi, N. (2018). Analisis altman z-score untuk memprediksi kebangkrutan pada Bank Pemerintah (BUMN) di Indonesia Tahun 2012-2016. Jurnal Sekuritas, Vol.1, No.3, Maret 2018, 142 - 156.

Kasmir. (2014). Analisis Laporan Keuangan. Jakarta: PT. Raja Grafindo Persada.

Kasmir. (2014). Bank dan Lembaga Keuangan Lainnya . Jakarta: PT. Raja Grafindo Persada.

Keown AJ, M. J. (2010). Financial Management: Priciples and Applications 10th Edition. Diterjemahkan oleh: Marcus Priminto Widodo, M.A. 2010.Manajemen Keuangan; Prinsip dan Penerapan. Jakarta: PT Indeks.

Nardi Sunardi, A. A. (2018). Determinant Of Cost Efficiency And It's Implications For Companies Performance Incorporated In The Lq.45 Index Listing In Idx For The Period of 2011-2016,. International Journal of Applied Business and Economic Research, 16(Companies Performance).

Nardi Sunardi, E. A. (2018). Effects Of The Bank Soundness With The Rbbr Approach (Risk Base Bank Rating) Of Cost Efficiency And Its Implications On Sharia Bank Performance In Indonesia For The Period Of 2012 - 2016,. International Journal of Economic Research, 15(Bank Soundness).

Nazir, A. K. (2014). Capital Structure and Firm Value: Empirical Capital Structure and Firm Value: Empirical. Capital Structure and Firm Value: Empirical, 1(Firm Value), 11-12.

Pujiastuti, S. H. (2015). Dasar-dasar Manajemen Keuangan. Yogyakarta: UPP STIM TKPN, Yogyakarta.

Sari, I. (2010). Pengaruh Mekanisme Good Corporate Governance Terhadap Kinerja. Skripsi.

Suburmayam KR, W. J. (2014). Financial Statetment Analysis 10th Edition.Diterjemahkan oleh: Dewi Yanti. 2014. Analisis Laporan Keuangan. Jakarta:: Salemba Empat. 
Sugiyono. (2012). Metodologi Penelitian Kuantitatif Kualitaif dan $R \& D$. Bandung: CV. Alfabeta .

Sukirno, S. (2002). Teori Mkro Ekonomi. Jakarta: Rajawali Press.

Sunardi, L. H. (2017). determinant of leverage and it's implication on company value of real estate and property sector listing in IDX period of 2011-2015. Man In India, 97(Financial Management), 131-148.

Sunardi, N. (2017). Determinan Kebijakan Utang serta Implikasinya Terhadap Perusahaan (Perusahaan yang tergabung dalam indeks LQ.45 yang terdaftar di BursaEfek Indonesia Tahun 2011- 2015). Jurnal Sekuritas, 78-97.

Sunardi, N. (2018). Determinant of cost efficiency and it's implications for companies performance incorporated in the LQ.45 Index Listing in IDX the Priod of 20112016. International Journal of Applied Business and Economic Reserch, 16(Companies Performance), 17-28.

Sunardi, N. (2018). Relevansi Struktur Kepemilikan Tentang Profitabilitas dan Nilai Perusahaan (Studi pada Industri Manufaktur yang terdaftar di Bursa Efek Indonesia Periode 2010-2017). PROCEEDINGS (Vol. 1, No. 1).

Sunardi, N., \& Permana, D. I. ( 2019 ). FAKTOR-FAKTOR YANG MEMPENGARUHI HARGA SAHAM DAN DAMPAKNYA PADA NILAI PERUSAHAAN. JIMF (Jurnal IImiah Manajemen Forkamma), 62-72.

Veno, A. (2015). Pengaruh Good Corporate Governance terhadap Kinerja Perusahaan pada Perusahaan Manufaktur Go Public. BENEFIT Jurnal Manajemen dan Bisnis, 95-112." 